\title{
Synthesis and Properties of 1-Substituted Benzoyl Aminopropyl Silatranes
}

\author{
Zhonghua Li, Huaping Su, Xianyin Gao and Qiuping Tian \\ College of Chemistry, Huazhong Normal University, Wuhan 430079 China
}

\begin{abstract}
Ten substituted benzoyl aminopropyl silatranes have been synthesized by the reaction of aminopropyl silatrane with various substituted benzoyl chlorides. IR, 'HNMR and elemental analysis confirmed their structures. The antibacterial test showed that they were efficient against Cucumber Mildew.
\end{abstract}

Key words: Silatrane, acyl thiourea, benzoyl isocyanate, biological activity, synthesis

\section{INTRODUCTION}

Silatranes have outstanding biological activities and their biological activity is greatly related to the substituents on silicon atom $/ 1,2 /$. Acyl substituted thiourea derivatives are also known to possess various biological activities, It has been reported that phenylureas and thioureas form the basis of many molecules possessing biological activity; some of them are successfully used as insecticides $/ 3 /$, bactericides $/ 4 /$, and plant growth regulators $/ 5 /$.

We have synthesized a series of silatranes containing arylsulfonyl and phosphoryl groups $/ 6,7 /$, and most of them are proved to possess special biological properties. In order to study the properties of different substituted silatrane derivatives, ten benzoyl thioureylenepropyl silatranes $(1-10)$ were prepared in the present work by the reaction of aminopropyl silatrane with substituted benzoyl isocyanates produced from benzoic acids (Scheme 1).

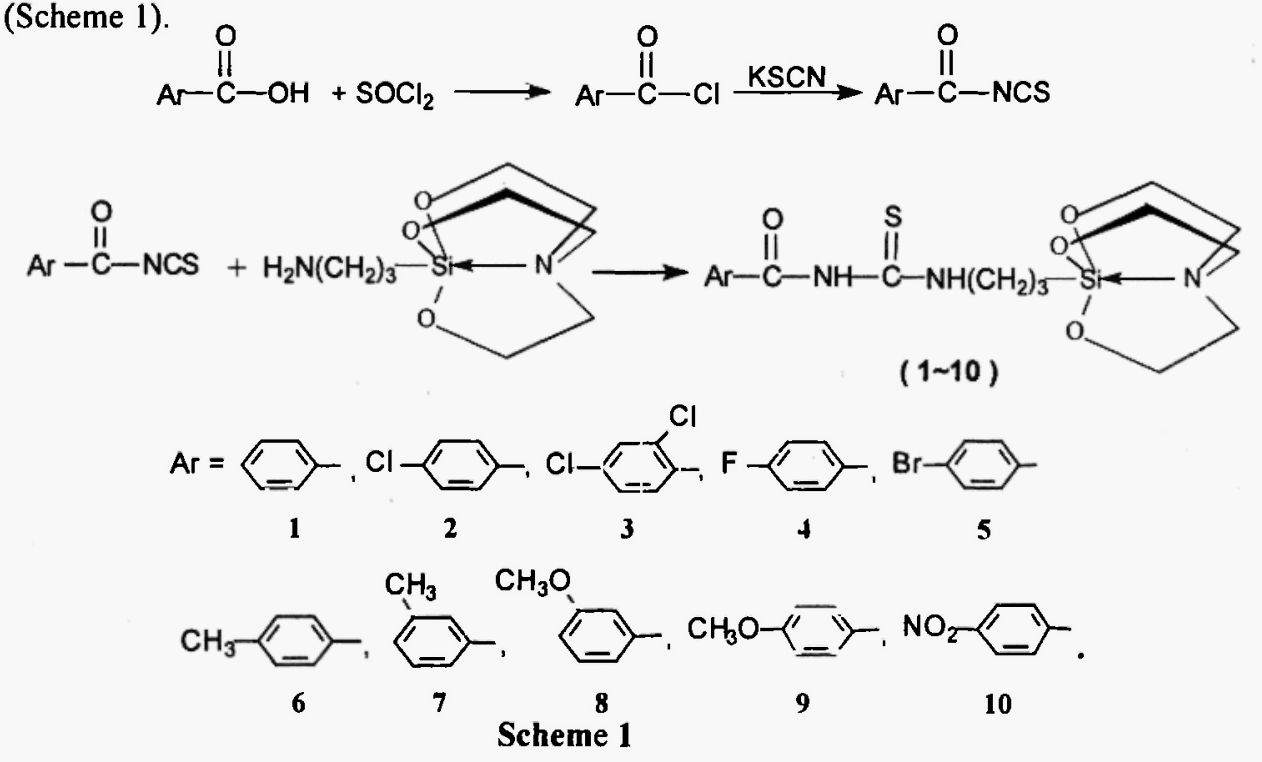




\section{EXPERIMENTAL}

IR were recorded on a PE-983 spectrophotometer ( $\mathrm{KBr}$ pellets), ${ }^{1} \mathrm{HNMR}$ were obtained in $\mathrm{CDCl}_{3}$ using TMS as an internal standard on a Varian Associates EM-360 spectrometer, Elemental analyses were performed on a PE-2400 automatic meter, Melting Points were determined with an X4-Meltler and thermometer uncorrected.

Aminopropyl silatrane was prepared by the transesterificaction of triethanolamine and 3aminopropyltriethoxysilane /8/.

Synthesis of the target compounds: A mixture of $10 \mathrm{mmol}$ benzoic acid and $12 \mathrm{mmol}$ sulfonyl chloride was stirred and refluxed at $70-75^{\circ} \mathrm{C}$ till without hydrogen chloride gave out, distilled out the extra sulfonyl chloride, a solution of $15 \mathrm{mmol}$ potassium thiocyanate in $30 \mathrm{ml}$ acetonitrile was added, stirred at $70^{\circ} \mathrm{C}$ for half a hour and filtrated, the filtrated solution was added dropwise to a mixture of $10 \mathrm{mmol}$ aminopropyl silatrane, $10 \mathrm{mmol}$ triethylamine and $10 \mathrm{ml}$ chloroform in a cold water bath, then the mixture was refluxed for $2 \mathrm{~h}$, suspended matter was separated out from the mixture, evaporated and precipitate occurred from the remainder. Recrystallization from acetone and ethanol afforded 1 (84\%) with m.p. 190-192 5 . 2-10 were prepared in the same way.

\section{RESULTS AND DISCUSSIONS}

The reaction of substituted benzoyl isocyanate and aminopropyl silatrane belongs to nucleophilic addition; an acyl group greatly increases the reactivity. Different substituents and their position on the benzene ring have a significant effect on the reaction. The presence of electron-withdrawing groups at ortho or para position of benzoyl is favorable for nucleophilic attack and enhances the rate of the reactions, but the electron-donating groups inactivate the reactions. The reaction of $\mathrm{p}$-nitrobenzoyl isocyanate with aminopropyl silatrane, for example, is completed smoothly in tens of minutes, but p-methyl benzoyl analogues even need a few hours.

The facility of silyl ethers and esters to hydrolysis is well known, but the presence of $\mathrm{Si} \leftarrow \mathrm{N}$ transannular interaction decreases the effective charge on the silicon atom and hinders nucleophilic attack by water or hydroxyl ion, so that silatranes are relatively more stable to hydrolysis than the corresponding derivatives of trialkoxysilane /9/. It was known that acidic condition could cause the silatrane ring cleavage and lead to further polymerization $/ 10 \%$. To avoid these unnecessary reactions, an acid capture material was indispensable. In this case, tertiary amine or pyridine was the first selection for removing the acidic substance produced in the reaction; meanwhile, the temperature should be controlled carefully to ensure that the reaction is completed.

Table 1 and Table 2 give the experimental results, elemental analysis, IR and ${ }^{1} H N M R$ data of the compounds $1-10$ respectively. 
Li et al.

Main Group Metal Chemistry

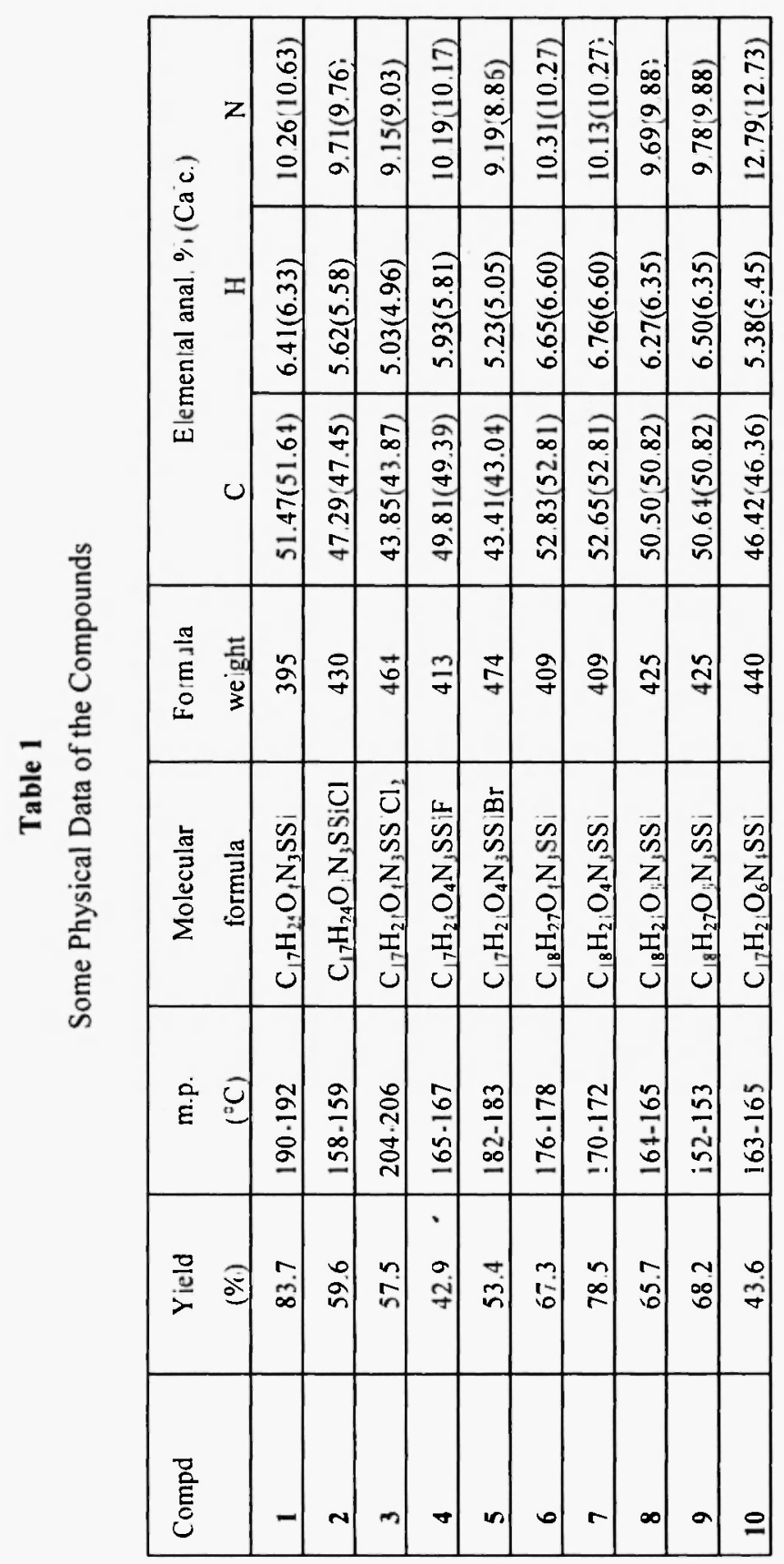

103 
It was known that the formation of $\mathrm{Si} \leftarrow \mathrm{N}$ feedback coordinate bond by the unshared nitrogen electron pair with the vacant $3 \mathrm{~d}$ orbitals on silicon atom was a distinguishing property of silatranes $/ 11$. This peculiar electronic trait of the silatrane molecules could be easily observed in their IR and NMR spectra.

The vibration frequencies of the coordinate $\mathrm{Si} \leftarrow \mathrm{N}$ bond in silatranes are in the region $585-590 \mathrm{~cm}^{-1}$, which is lower than that of the ordinary $\mathrm{Si}-\mathrm{N}$ bond in silylamines $\left(810-830 \mathrm{~cm}^{-1}\right) / 121$. A comparison of the $\mathrm{SiCH}_{2}$ and $\mathrm{OCH}_{2}$ proton chemical shift in silatranes respectively with those in $\mathrm{CH}_{3} \mathrm{Si}\left(\mathrm{OCH}_{2} \mathrm{CH}_{3}\right)_{3}$ and $\mathrm{N}\left(\mathrm{CH}_{2} \mathrm{CH}_{2} \mathrm{OH}\right)_{3}$ revealed that the $\mathrm{Si} \leftarrow \mathrm{N}$ bond formation led to screening of the silicon atom but the nitrogen atom became unscreened. The chemical shift is consistent with the trigonal bipyramidal model that would certainly appear to involve increased electron supply at the silicon atom.

Table 2

Spectral Data of the Compounds

\begin{tabular}{|c|c|c|}
\hline Compd & $\mathrm{IR}(\mathrm{KBr}) \mathrm{v}\left(\mathrm{cm}^{\prime}\right)$ & ${ }^{1} \mathrm{HNMR}\left(\mathrm{CDCl}_{3}\right) \delta(\mathrm{ppm})$ \\
\hline 1 & $\begin{array}{l}3353,3159(\mathrm{~N}-\mathrm{H}), 1690(\mathrm{C}=\mathrm{O}) \\
1554 \\
1516(\mathrm{Ar}), 1196(\mathrm{C}=\mathrm{S}), 1102,1018 \\
(\mathrm{Si}-\mathrm{O}-\mathrm{C}), 586(\mathrm{Si} \leftarrow \mathrm{N})\end{array}$ & $\begin{array}{l}11.21(\mathrm{~s}, 1 \mathrm{H}, \mathrm{NH}), 10.88(\mathrm{~s}, 1 \mathrm{H}, \mathrm{NH}), 7.49-7.93(\mathrm{~m}, 5 \mathrm{H}, \mathrm{Ar}-\mathrm{H}) \\
3.88(\mathrm{t}, 6 \mathrm{H}, \\
\left.\mathrm{OCH}_{2}\right), 3.36\left(\mathrm{~m}, 2 \mathrm{H}, \mathrm{NHCH}_{2}\right), 2.80\left(\mathrm{t}, 6 \mathrm{H}, \mathrm{CH}_{2} \mathrm{~N}\right), 1.62\left(\mathrm{~m}, 2 \mathrm{H}, \mathrm{CH}_{2}\right) \\
0.21\left(\mathrm{t}, 2 \mathrm{H}, \mathrm{CH}_{2} \mathrm{Si}\right)\end{array}$ \\
\hline 2 & $\begin{array}{l}3354,3104(\mathrm{~N}-\mathrm{H}) \\
1675(\mathrm{C}=\mathrm{O}), 1546 \\
1475(\mathrm{Ar}), 1195(\mathrm{C}=\mathrm{S}), 1108,1032 \\
(\mathrm{Si}-\mathrm{O}-\mathrm{C}), 583(\mathrm{Si} \leftarrow \mathrm{N})\end{array}$ & $\begin{array}{l}11.12(\mathrm{~s}, 1 \mathrm{H}, \mathrm{NH}), 10.89(\mathrm{~s}, 1 \mathrm{H}, \mathrm{NH}), 7.02-7.97(\mathrm{~m}, 4 \mathrm{H}, \mathrm{Ar}-\mathrm{H}), 3.80(\mathrm{t}, \\
\left.6 \mathrm{H}, \mathrm{OCH}_{2}\right), 3.40\left(\mathrm{~m}, 2 \mathrm{H}, \mathrm{NHCH}_{2}\right), 2.78\left(\mathrm{t}, 6 \mathrm{H}, \mathrm{CH}_{2} \mathrm{~N}\right), 1.65\left(\mathrm{~m}, 2 \mathrm{H}, \mathrm{CH}_{2}\right) \text {, } \\
0.22\left(\mathrm{t}, 2 \mathrm{H}, \mathrm{CH}_{2} \mathrm{Si}\right),\end{array}$ \\
\hline 3 & $\begin{array}{l}3435,3213(\mathrm{~N}-\mathrm{H}) \\
1672(\mathrm{C}=\mathrm{O}), 1550 \\
1546(\mathrm{Ar}), 1197(\mathrm{C}=\mathrm{S}), 1082,1015 \\
(\mathrm{Si}-\mathrm{O}-\mathrm{C}), 582(\mathrm{Si} \leftarrow \mathrm{N})\end{array}$ & $\begin{array}{l}11.30(\mathrm{~s}, 1 \mathrm{H}, \mathrm{NH}), 10.78(\mathrm{~s}, 1 \mathrm{H}, \mathrm{NH}), 7.12-8.04(\mathrm{~m}, 3 \mathrm{H}, \mathrm{Ar}- \\
\mathrm{H}), 3.85(\mathrm{t}, 6 \mathrm{H}, \\
\left.\mathrm{OCH}_{2}\right), 3.36\left(\mathrm{~m}, 2 \mathrm{H}, \mathrm{NHCH}_{2}\right), 2.74\left(\mathrm{t}, 6 \mathrm{H}, \mathrm{CH}_{2} \mathrm{~N}\right), 1.60\left(\mathrm{~m}, 2 \mathrm{H}, \mathrm{CH}_{2}\right) \\
0.24\left(\mathrm{t}, 2 \mathrm{H}, \mathrm{CH}_{2} \mathrm{Si}\right)\end{array}$ \\
\hline 4 & $\begin{array}{l}3323,3150(\mathrm{~N}-\mathrm{H}) \\
1668(\mathrm{C}=\mathrm{O}), 1554 \\
1483(\mathrm{Ar}), 1193(\mathrm{C}=\mathrm{S}), 1190,1015 \\
(\mathrm{Si}-\mathrm{O}-\mathrm{C}), 585(\mathrm{Si} \leftarrow \mathrm{N})\end{array}$ & $\begin{array}{l}11.25(\mathrm{~s}, 1 \mathrm{H}, \mathrm{NH}), 10.75(\mathrm{~s}, 1 \mathrm{H}, \mathrm{NH}), 7.05-7.98(\mathrm{~m}, 4 \mathrm{H}, \mathrm{Ar}- \\
\mathrm{H}), 3.86(\mathrm{t}, 6 \mathrm{H}, \\
\left.\mathrm{OCH}_{2}\right), 3.38\left(\mathrm{~m}, 2 \mathrm{H}, \mathrm{NHCH}_{2}\right), 2.81\left(\mathrm{t}, 6 \mathrm{H}, \mathrm{CH}_{2} \mathrm{~N}\right), 1.63\left(\mathrm{~m}, 2 \mathrm{H}, \mathrm{CH}_{2}\right) \\
0.20\left(\mathrm{t}, 2 \mathrm{H}, \mathrm{CH}_{2} \mathrm{Si}\right)\end{array}$ \\
\hline 5 & $\begin{array}{l}3350,3139(\mathrm{~N}-\mathrm{H}) \\
1664(\mathrm{C}=\mathrm{O}), 1552 \\
1467(\mathrm{Ar}), 1191(\mathrm{C}=\mathrm{S}), 1102,1018 \\
(\mathrm{Si}-\mathrm{O}-\mathrm{C}), 583(\mathrm{Si}-\mathrm{N})\end{array}$ & $\begin{array}{l}11.36(\mathrm{~s}, 1 \mathrm{H}, \mathrm{NH}), 10.82(\mathrm{~s}, 1 \mathrm{H}, \mathrm{NH}), 7.01-7.94(\mathrm{t}, 4 \mathrm{H}, \mathrm{Ar}-\mathrm{H}), 4.92(\mathrm{~s} \\
\left.2 \mathrm{H}, \mathrm{CH}_{2}\right), 3.82\left(\mathrm{t}, 6 \mathrm{H}, \mathrm{OCH}_{2}\right), 3.35\left(\mathrm{~m}, 2 \mathrm{H}, \mathrm{NHCH}_{2}\right), 2.84\left(\mathrm{t}, 6 \mathrm{H}, \mathrm{CH}_{2} \mathrm{~N}\right) \\
0.22\left(\mathrm{t}, 2 \mathrm{H}, \mathrm{CH}_{2} \mathrm{Si}\right)\end{array}$ \\
\hline 6 & $\begin{array}{l}3315,3155(\mathrm{~N}-\mathrm{H}) \\
1660(\mathrm{C}=\mathrm{O}), 1538, \\
1521(\mathrm{Ar}), 1197(\mathrm{C}=\mathrm{S}), 1121,1016 \\
(\mathrm{Si}-\mathrm{O}-\mathrm{C}), 585(\mathrm{Si} \leftarrow \mathrm{N})\end{array}$ & $\begin{array}{l}11.13(\mathrm{~s}, 1 \mathrm{H}, \mathrm{NH}), 10.88(\mathrm{~s}, 1 \mathrm{H}, \mathrm{NH}), 7.16-8.01(\mathrm{~m}, 4 \mathrm{H}, \mathrm{Ar}-\mathrm{H}), 3.85(\mathrm{t}, \\
\left.6 \mathrm{H}, \mathrm{OCH}_{2}\right), 3.82\left(\mathrm{t}, 6 \mathrm{H}, \mathrm{CH}_{2} \mathrm{~N}\right), 3.34\left(\mathrm{~m}, 2 \mathrm{H}, \mathrm{NHCH}_{2}\right), 1.62\left(\mathrm{~m}, 2 \mathrm{H}, \mathrm{CH}_{2}\right), \\
0.22\left(\mathrm{t}, 2 \mathrm{H}, \mathrm{CH}_{2} \mathrm{Si}\right)\end{array}$ \\
\hline
\end{tabular}


Table 2 (continued)

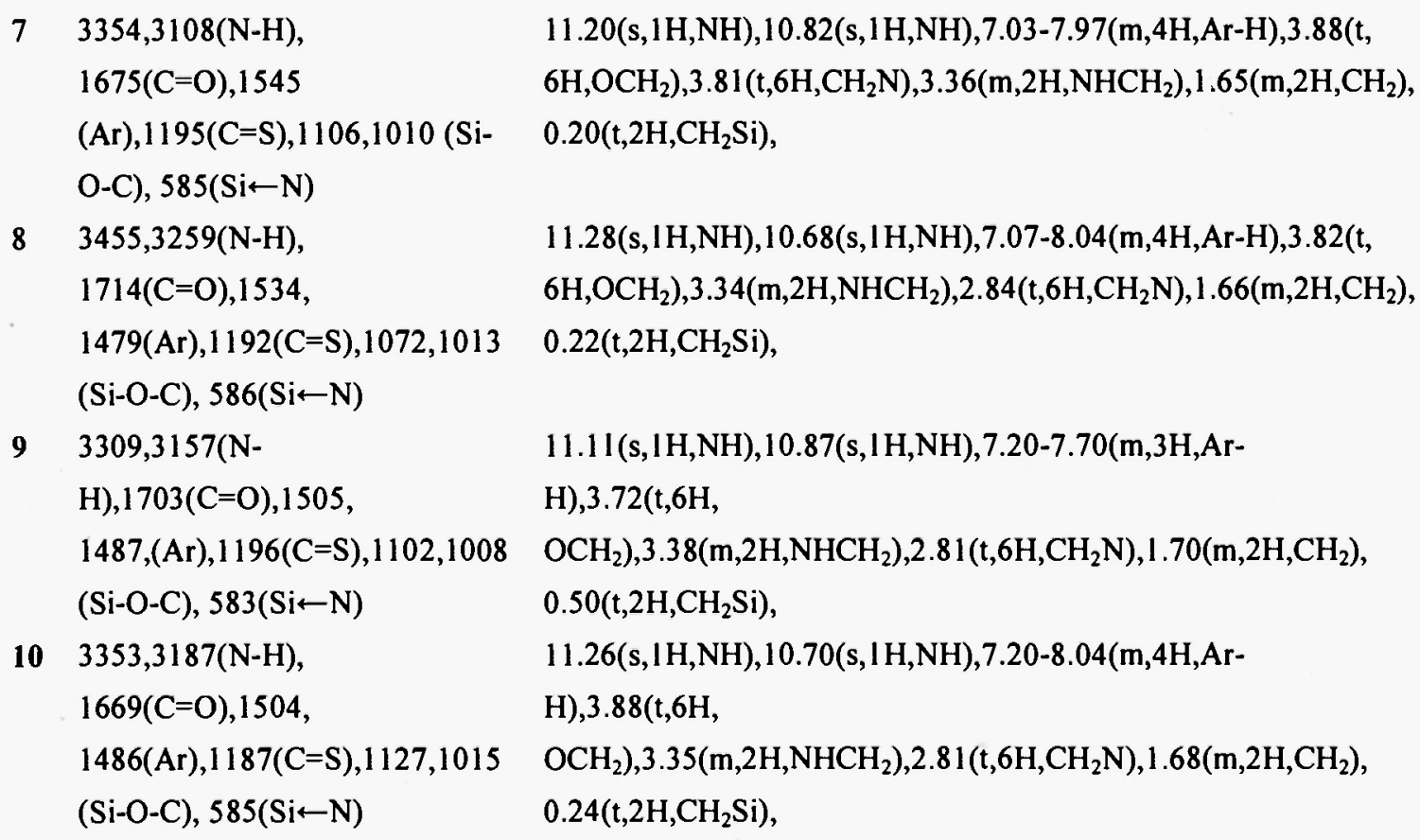

Antibacterial activity was preliminarily tested for the compounds on Cotton Fusarium Wilt, Rice Sheath Blight, Cucumber Mildew, Wheat Scab, Apple Ring Rot, and Corn Leaf Blight. Table 3 gives the inhibition of the compounds to these fungi (the concentration is $50 \mu \mathrm{l} / \mathrm{L}$ and compared with DMF as a standard). The results showed that the compounds had remarkable activity for all the bacteria, especially for Cucumber Mildew.

Table 3

Inhibition of the compounds for bacterials (\%)

\begin{tabular}{lcccccc}
\hline Compd. & Cotton Fusarium & $\begin{array}{c}\text { Rice Sheath } \\
\text { Blight }\end{array}$ & $\begin{array}{c}\text { Cucumber } \\
\text { Mildew }\end{array}$ & Wheat Scab & $\begin{array}{c}\text { Apple Ring } \\
\text { Rot }\end{array}$ & $\begin{array}{c}\text { Corn Leaf } \\
\text { Blight }\end{array}$ \\
\hline 1 & 48.00 & 68.04 & 85.37 & 44.12 & 57.89 & 62.50 \\
2 & 52.00 & 70.10 & 85.37 & 41.18 & 63.16 & 81.25 \\
3 & 40.00 & 64.95 & 87.80 & 41.18 & 42.11 & 62.50 \\
4 & 64.00 & 85.57 & 97.56 & 64.71 & 73.68 & 81.25 \\
5 & 48.00 & 71.13 & 78.05 & 52.94 & 63.16 & 62.50 \\
6 & 56.00 & 76.29 & 95.12 & 55.88 & 68.42 & 75.00 \\
7 & 48.00 & 73.20 & 90.24 & 44.12 & 63.16 & 68.75 \\
8 & 48.00 & 63.92 & 78.05 & 44.12 & 78.95 & 81.25 \\
9 & 56.00 & 77.32 & 98.78 & 55.88 & 57.89 & 81.25 \\
10 & 48.00 & 77.32 & 82.93 & 55.88 & 42.11 & 75.00 \\
\hline
\end{tabular}




\section{REFERENCES}

1. M. G. Voronkov, Biochemistry of Silicon and Related Problems. New York/London: Plenum Press, (1978).

2. Z. H. Li and C. F. Zhu, Silicone Material and Applications. 10 (1), 1(1996).

3. E Schroepel, et al, Pharmazie, 23 (9), 484(1968)

4. T. B. Brown and R. L. Harris, Past. Sci., 4 (2), 215(1973).

5. V. K. Madan and A. D. Taneja, J. Indian Chem.Soc., 68 (3), 162(1991).

6. Z. H. Li and D. M.Tian, Heterocyclic Commun., 9 (6), 605(2003).

7. Z. H. Li and X.Y. Song, Phosphorus, Sulfur Silicon Related Elements, 179 (7), 1411(2004).

8. Z. H. Li, D. M. Tian and C. F. Zhu, Phosphorus, Sulfur Silicon Related Elements. 165 (1), 99(2000).

9. P. Hencsei and L. Parkanyi, J. Organomet. Chem. 8, 191(1985)

10. V. F. Pestunvich, S. V. Kirpichenko, and M. G. Voronkov, Chem. Org. Silicon Compd., 2,1447 (1998)

11. X. D. Zhang, G. Zheng, et al. Huaxue Xuebao, 56 (10), 986(1998).

12. S. Patai, Z. Rappoport, The Chemistry of Organic Silicon Compounds. Part 1, John Wiley \& Sons, Chichester-New York-Brisbane, (1989). 